\title{
SOMOGYI SZILVIA
}

\section{Az esztergomi szinodális könyvről: új források, redakciók és szövegtöbbletek nyomában}

\author{
Elötanulmány egy disszertációfejezethez
}

\begin{abstract}
Az esztergomi szinodális könyv a középkori magyar egyháztörténet egyik legfontosabb forrása. Az esztergomi egyházmegye késő középkori zsinati tevékenységének emlékét őrző zsinati határozatok szövegkiadásával, forrásainak feltárásával hosszú évszázadok óta foglalkozik a kutatás. E zsinati határozatoknak Erdő Péter monográfiája ${ }^{1}$ és a korábbi szövegkiadások, szövegközlések nyomán mindezidáig három igazán jelentős változatát, átszerkesztését, bővítését tartották számon. A legkorábbi változatot Demeter esztergomi érsek hirdette ki 1382-ben. ${ }^{2}$ Ennek szövegét az Egyetemi Könyvtár Cod. Lat. 73-as középkori kódexe alapján Batthyány Ignác tette közzé. ${ }^{3}$ A második, 1450 -es változat, Szécsi Dénes esztergomi érsek nevéhez köthető. Ezt az ősnyomtatványból ismert szövegváltozatot Batthyány Ignác és Dankó József is kiadta. ${ }^{4}$ A harmadik, 1493 -as, Estei Hippolit érsek általi megújítás szövegét szintén egy ősnyomtatvány örzi. ${ }^{5}$

Noha filológusok nemzedékei tanulták meg az egyetemen, hogy kritikai szövegkiadások készítése során alkalmazzák az elvet, amely szerint „codices recentiores non sunt deteriores", és amely alapján tudták, hogy néha a kései ősnyomtatványok filológiailag jóval értékesebb szöveget tartalmaznak, mint néhány korábbi középkori kódex szöveghordozó, ${ }^{6}$ a magyar egyháztörténészeket mégis némi csalódással tölthette el a kutatás felismerése, hogy az esztergomi szinodális könyv középkori szövegváltozatainak igen kevés (középkori) kódex hordozója vált részleteiben is ismertté. ${ }^{7}$ Szerencsés kivétel egy középkorban írni
\end{abstract}

${ }^{1}$ ERDő Péter, Egyházjog a középkori Magyarországon, Bp., Osiris, 2001, 25-53.

${ }^{2}$ Erröl ld.: Uo. 29, 41.

3 Batthyany, Ignác, Leges ecclesiasticae regni Hungariae et provinciarum adiacentium, I-III, Albae Carolinae-Claudiopoli, 1785-1827, III, 260-278 (a továbbiakban BATTHYANY, Leges).

${ }^{4}$ Dankó József, Constitutiones synodales almae ecclesiae Strigoniensis A. D. MCCCCL, Strigonii, 1865, 1-32; BatthyAnY, Leges III, 466-491.

${ }^{5}$ Batthyany, Leges III, 546-566.

${ }^{6}$ Havas László, A szövegkritika = Bevezetés az ókortudományba I. A görög és római világ irásos és tárgyi emlékei, ed., Havas, László, Tegyey, Imre Debrecen, Kossuth Egyetemi Kiadó, 1998, 67-100.

${ }^{7}$ A középkori részleges egyházjog magyarországi kódex szöveghordozóiról részletesen: ERDŐ 2001, i. m. 78-82; a középkori esztergomi zsinati szöveget tartalmazó ősnyomtatványokról: BoRSA Gedeon, Hazai egyházmegyék Mohács elött nyomtatott zsinati határozatai = Magyar Könyvszemle, 102(1986), 67-74. 
kezdett brassói kódex, amelyre Solymosi László hívta fel a figyelmet, egyrészt az 1515-ös veszprémi zsinati könyv szövegkiadásában, másrészt egy külön tanulmányban, amelyet az esztergomi egyházmegye legrégibb ünneplajstromáról írt. ${ }^{8}$ A kódexet Kanizsai János esztergomi érsek szinodális könyveként írta le, feltételezvén, hogy a zsinati határozatok prológusa egy (valószínüleg) 1388 és 1394 között valamelyik évben megtartott esztergomi zsinatról származhat, a zsinati könyvben hagyományozott szöveganyag pedig Kanizsai János esztergomi érseki tevékenységének teljes idejét felölelheti, ${ }^{9}$ ám a szövegváltozat kiadására és részletes elemzésére még nem került sor. Ennek egyik oka minden bizonnyal az volt, hogy miként az esztergomi szinodális könyv másik három változatának $(1382,1450,1493)$ szövege is igen közel áll egymáshoz, bővített és némiképp módosított változatok, úgy - első pillantásra - ez a szöveg az 1382-es szövegredakcióhoz áll közel, és mint ilyen, mind szövegkritikai, mind egyháztörténeti szempontból kevéssé értékes.

Az esztergomi szinodális könyv kevéssé vizsgált szövegváltozatának említett brassói kódex szöveghordozója a brassói dékánság középkori Kézikönyve. Ez egy 15. században, egészen pontosan 1452-ben, az akkori brassói dékán, György által vezetni kezdett használati könyvszerü, tartalmában vegyes kódex. ${ }^{10} \mathrm{Az}$ esztergomi zsinati szöveg minden bizonnyal azért került bele a kódexbe, mert a brassói dékánság a 15. század közepén közvetlenül az esztergomi érsek joghatósága alatt állt, és ebből a tényből kifolyólag a mindenkori brassói dékánok az esztergomi egyházmegyei zsinaton voltak kötelesek megjelenni, az esztergomi egyházmegye zsinati határozatai voltak relevánsak a dékánság területén tevékenykedő papok számára. Mivel a Kézikönyv reménybeli, készülő disszertációm tárgya, elkerülhetetlenné vált a benne található esztergomi zsinati szöveg részletesebb vizsgálata. Az első látásra kevés újdonságot tartogató szöveg átírása és értelmezési kísérlete váratlan meglepetésekkel szolgált, ez a rövid írás a meglepetések felfedésére vállalkozik, a részletes és pontos elemzésre teret maga a disszertáció adhat. A meglepetéseket a címben megjelölt három tárgykör (új források, szövegtöbbletek, redakciók) szerint rendezem el.

${ }^{8}$ Solymosi László, A veszprémi egyház 1515. évi zsinati határozatai, Bp., Argumentum, Balassi, 1997, 31, 42.

9 Solymosi László, Az esztergomi egyházmegye legrégebbi ünneplajstroma (Szent Adalbert, Szórád-András és Benedek tisztelete az erdélyi szászoknál) $=R$. Várkonyi Ágnes Emlékkönyv születésének 70. évfordulója ünnepére, szerk. Tusor Péter, Bp., 1998, 88-95.

${ }^{10}$ DF $28663517 \mathrm{r}-30 \mathrm{v}$, ma a brassói Honterus Levéltár őrzi, régi barcasági káptalani jelzete: I-E-144. A kódex tartalmáról és leírásáról részletesebben: Somogy Szilvia, A brassói dékánság Kézikönyvének egyik kánonjogi jegyzete, Adalékok az egyházi bíráskodás illetékességi körének történetéhez = Micae mediaevales VII. Fiatal történészek dolgozatai a középkori Magyarországról és Európáról, szerk. Farkas Csaba, Ribi András, Veres Kristóf György, Bp., ELTE BTK Történelemtudományok Doktori Iskola, 2018, 149-165, kül. 149. 


\section{Új források}

Erdő Péter először 1997-ben publikált írásában az 1382-es esztergomi zsinati könyv legfontosabb forrásaként a krakkói egyházmegyében Nanker püspök által 1320-ban kiadott zsinati statútumokat határozta meg. Felfedezése óriási jelentőségü volt, hiszen ezáltal ismertté vált, hogy a zsinati könyv 1382-es változatát kitevő szöveg 55-60 százaléka szinte teljes mértékben (90 százalékban) megegyezik feltételezett lengyel forrásának szövegével. ${ }^{11}$ Az egyező szövegrészek a szentségekről, ezek kiszolgáltatásáról és őrzéséről, - vagy ahogyan ezt a latin szöveg pontosabban megfogalmazza: „Primo: in ecclesiasticorum sacramentorum administratione. Secundo: in eorundem cauta custodia, et contrectatione. Tertio: in divinorum officiorum celebratione. Quarto: in animarum, et ecclesiarum regimine, et dispositione." 12 - szólnak. Bár a szerző maga is felhívta rá a figyelmet, hogy a szinte teljes mértékben megegyező szöveghelyek kollacionálása is azt sugallja, hogy a mondott esztergomi szövegrészeknek vagy volt más, kisebb mértékben felhasznált forrása is, vagy a krakkói szinodális könyvről nem teljes a szövegkritikai tudásunk. ${ }^{13}$ Mindezidáig más zsinati források nem jöttek szóba az esztergomi szövegtörzs adott szakaszainak forrásaiként.

A brassói kódexben lévő zsinati szöveg a fent említett tartalmi egységeiben, azaz a szentségekkel kezdődő négyosztatú szövegben, teljes egyezést mutat az esztergomi zsinati szöveg 1382-es változatával, és ezáltal forrásai is megegyeznek annak forrásaival. A szöveg prológusának olvasása közben vált világossá számomra, hogy míg mind a krakkói, mind az esztergomi határozatok bevezetője utal rá, hogy egy négy részből álló szövegegységgel fognak kezdődni a határozatok, ${ }^{14}$ addig az esztergomi változatban egy jóval bővebb, a négy tartalmi egységet indokló, retorikailag kimunkált és összefüggő prológus szerepel - a Fratres carissimi kezdetü -, addig ez a bevezető a krakkói szövegből szinte teljes egészében hiányzik, sőt a szöveg négyes osztatára utaló bevezető meglehetósen rövidítettnek, csonkítottnak tünik. Ebből a felismerésből három dolog következhet. Az egyik, hogy a Fratres carissimi kezdetü bevezető magyar találmány, magyar író tollán született. A másik, hogy az esztergomi zsinat a határozatok ezen a pontján nem közvetlenül a krakkói zsinati határozatok (általunk ismert) szövegéről má-

11 ERDÖ 2001, i. m. 43-44.

12 Batthyany, Leges III, 261, a krakkói és esztergomi statútumok fejezeteinek megegyezéséről: ERDÖ 2001, i. m. 48.

${ }^{13}$ ERDÖ 2001, i. m. 45.

${ }^{14}$ A fent idézett esztergomi szöveg latin megfelelöje a krakkói szövegben: „Sane quia viris ecclesiasticis duo principaliter sunt necessaria, videlicet vita et conversacio irreprehensibilis, nec non sciencia scripturarum, illa precipue, que in quatuor consistit: primo, in sacramentorum administracione; secundo, in eorum cauta custodia et contractacione; tercio, in divinorum officiorum celebracione; quarto, in animarum ac ecclesiarum regimine ac disposicione [...]:" Statuta synodalia episcoporum Cracoviensium XIV et XV saeculi e codicibus manu scriptis typis mandata additis statutis Vielunii et Calissii a. 1420 conditis, ed. Udalricus HeyzMann, Cracoviae, 1875, 4. 
solt, hanem valamely más forrásról. A harmadik, szintén logikusnak tűnő következtetés, hogy az esztergomi szövegnek és a krakkói szövegnek van egy közös „ősforrása”, azaz az esztergominak nem szükségszerüen a krakkói a legfontosabb forrása, hanem egy olyan szöveg, amely már a krakkói statútumoknak is a forrása volt. Hogy ez utóbbi bizonyítható legyen, két dolognak egyszerre kellene megvalósulnia. Találni kellene egy olyan zsinati könyvet, amelyben szerep a szöveggel teljes tartalmi és tematikai egységet alkotó, Fratres carissimi kezdetü prológus. A másik, hogy ennek szükségképpen korábbinak kellene lennie 1320-nál, hiszen máskülönben a krakkói határozatoknak nem lehetne a forrása, a krakkói prológus nem csonkulhatott volna belőle röviddé. A gondolkodás zsákutcáit nehézkes itt mondattá gyúrni, még nehézkesebb szöveggé formálni azokat a megérzéseket, amelyek a latin szavak átírása és ízlelgetése során váltak érzékelhetővé, így itt csak az eredményt foglalom össze. A krakkói és esztergomi zsinati határozatok szövegének négyes osztatú része nem Krakkóban született, a Fratres carissimi prológus pedig nem Esztergomban íródott.

A lengyel és a magyar zsinati könyvben (szinte teljesen) egyező négyosztatú szövegrészt először a paviai egyházmegye 1338-as, püspöke, Giovanni (IV) Fulsoni által kiadott zsinati határozataiban találtam meg..$^{15}$ A paviai zsinati határozatok tartalmazzák a Fratres carissimi kezdetủ zsinati prológust, sermo synodalist is ${ }^{16}$ valamint a négyosztatú szövegrész után még olyan fejezeteket (De sepulturis, De decimis, De censuris ecclesiasticis), ${ }^{17}$ amelyek az esztergomi szinodális könyv közvetlen forrásainak tekinthetők. Ha úgy tetszik, az esztergomi zsinati szöveg „hamarabb”, már a prológusnál kezdi követni a páviai egyházmegye statútumait, és azt a zsinati könyvet pár fejezettel tovább is „,veszi át”, mint a krakkóit. A kutatásnak ezen a pontján azt a tanulságot lehetett volna levonni, hogy az esztergomi zsinati szöveg 1382-es redakcióinak készítői előtt az 1320-as krakkói zsinati statútumok mellett, a paviai 1338-as egyházmegyei zsinati határozatok is ott hevertek, eddig titokzatosnak tủnő prológusának ez volt a forrása, ahol pedig a négyosztatú szöveg tekintetében a krakkói és esztergomi szövegek eltérnek egymástól, ott meg kell vizsgálni, hogy nem a paviai szöveg volt-e a kontamináció alapja. Ez az eredmény azonban továbbra sem szolgált volna magyarázattal arra, hogy miként rövidülhetett le a krakkói zsinati határozatok bevezetöje, ha a filológiai megérzés helyes. A paviai hagyományból semmiképpen, hiszen az (1338) későbbi a krakkóinál (1320). A paviai zsinati határozatok szövegkiadása sajnos nem szolgált komoly támponttal forrásairól, így némiképp homályban tapogatóztam, bár továbbra is az volt a benyomásom a szövegek latinsága alapján, hogy igen komoly egyetemes kánonjogi ismeretek birtokában megszerkesztett részletek. A gondolkodás újabb zsákutcáit itt is kihagyom, csak a következő fordulópontot kísérlem meg ismertetni. A paviai szöveget filológiailag

15 Concilia Papiensia constitutiones synodales et decreta dioecesana antehac separatim edita nunc in unum corpus collecta, ed. Johannes Bosisius, Papiae, 1852, 176-197.

16 Uo., 177.

17 Uo., 187-189. 
jóval kevésbé romlottnak, jóval tisztábbnak, érthetőbbnek, és valamivel bővebbnek láttam, mint a krakkói és az esztergomi zsinati szövegek vonatkozó részeit, így arra jutottam, hogy további források után mindenképpen olasz területeken érdemes kutatni. A paviai után a milánói egyháztartomány egy másik egyházmegyének, a novarainak 1298-ban, püspöke, Papiniano Della Rovere által kiadott zsinati határozataiban találtam meg a szentségekröl és őrzésükről szóló fejezeteket a Fratres carissimi prológussal együtt. ${ }^{18}$ A novarai zsinati határozatok keletkezési idejük alapján már eleget tehettek volna azoknak a feltételeknek, amelyeknek a paviaik nem, lehettek volna a krakkói zsinati határozatok forrásai, hiszen korábbiak a lengyelnél, a hosszabb bevezető szerepel bennük, ami csonkulhatott röviddé. A novarai zsinati határozatok elolvasása azonban egy ennél is fontosabb tanulsággal szolgált. Mályusz Elemér a középkori magyar egyházi társadalomról írt monográfiájában utalt rá, hogy nemcsak azzal kapcsolatban tapogatózunk homályban, hogy milyen forrásai voltak a késő középkori esztergomi zsinati könyvnek, hanem azzal kapcsolatban is, hogy a fejezetek miért ilyen sorrendben követik egymást, miért ilyen tematikájú a fejezetek elosztása. ${ }^{19}$ Az esztergomi, krakkói, paviai zsinati statútumokban hiába egyezik meg a fejezetek szövege és sorrendje hosszú-hosszú kaputokon át, semmi támpontot nem kapunk arra nézvést, hogy miért így épül fel a zsinati könyv. A novarai statútumokkal azonban más a helyzet. Papiniano Della Rovere a bevezetőben tematizálja a határozatok felépítését: „Nos Papinianus, miseratione divina episcopus Novariensis, de fratrum nostrorum capituli Novariensis consilio infrascriptas instructiones, monitiones et constitutiones in hac sancta synodo Novariensi in presentiarum ducimus promulgandas: primo quidem instructiones et monitiones, secundo constitutiones ponentes, ut sic bimembri tituli presens opusculum concludatur. ${ }^{20 "}$ Azaz két részből épül fel az 1298-es egyházmegyei zsinati könyv, ezek tartalmilag, formailag és bizonyos szempontból nyelvileg is jól elkülönülnek egymástól. Az első tematikai rész ,útmutatásokat és intéseket” (instructiones et monitiones), a második határozatokat (constitutiones) tartalmaz. A zsinati könyv az elöbbi meghatározást arra a bizonyos tizenegynéhány fejezetből álló négyosztatú szövegre alkalmazza, amely immár a négy egyházmegye (Novara, Pavia, Krakkó, Esztergom) teljesen megegyezik, a határozatokat tartalmazó része más tartamú. Tehát a zsinati könyveknek jól láthatóan ez az első része stabil, állandó, számos egyházmegyében felbukkanó, a másik rész variábilisabb és egyedibb. A novarai zsinati határozatok megtalálása megkönnyítette a helyzetemet, mert szövegének rendelkezésre áll modern kritikai kiadása a többi egyházmegye zsinati szövegével szemben, ez a kiadás a forrásokat is feltárta, így világossá vált, hogy sem a szentségekről és őrzésükről szóló szövegvariáns, sem egy zsinati könyv kétosztatú felépítése nem Novarrában bukkant fel elöször, a nyomok még távolabbra vezetnek, francia te-

${ }_{18}$ Gli statuti sinodali novaresi di Papiniano Della Rovere (a. 1298), ed. Giuseppe Briacca, Milano, 1971, 169-279, a vonatkozó részek 169-214.

19 Mályusz Elemér, Egyházi társadalom a középkori Magyarországon, Bp., Akadémiai, 1971, 347.

${ }^{20}$ Briacca ed. 1971, i. m. 169. 
rületekre, ahol a Mende egyházmegye számára készített zsinati könyvben bukkan fel először a szöveg. ${ }^{21} \mathrm{~A}$ Mende számára készült zsinati könyv első redakciója 1292-1293 körül készült el, írója pedig, akinek saját tolláról származtak a határozatok, a híres kánonjogász író Guillaume Durand (Wilhelmus Durandus), az adott időben Mende püspöke volt. Bár a munka használati zsinati könyv, jól látszik rajta a szerző kánonjogi képzettsége, az összes többi szövegváltozat ennek csak rövidített, használhatóbbra szabott variánsa.

Az eddig elmondottakat az alábbi módon foglalhatnám össze. A kánonjogász Wilhelmus Durandus, Mende püspökeként megalkotott egy olyan zsinati könyvet 1292-93-ban, amely mind szerkezetében, mind tartalmában utóbb számos egyházmegye zsinati határozatainak, zsinati könyveinek forrásává vált. Durandus a liber synodalist két részre osztotta, „útmutatásokra” (instructiones) és „határozatokra" (constitutiones), aztán pedig kihirdette őket az egyházmegyében, vagy ahogy ő fogalmazott: „Nos Guillelmus, sola Dei patientia episcopus Mimatensis, cupientes subjectos nostros in his que ad salutem animarum pertinere noscuntur feliciter gubernari, infrascriptas instructiones et constitutiones... ducimus promulgandas. Primo igitur instructiones, secundo vero constitutiones ponentur, sicque binario numero presentis libelli lectio peragetur." A zsinati könyv első része, amelyet a kánonjogász az instructiones latin terminussal illetett, önálló életre kelt. Bár a Durandus által tüpontosan megfogalmazott szöveg előbb kissé (Novara), utóbb erőteljesen (Pavia), majd még erőteljesebben (Krakkó, Esztergom) lerövidült, megcsonkult, a szöveg tartalmában és a fejezetek sorrendjében gyakorlatilag alig-alig állt be változás. A szentségekről és őrzésükről szóló részek eddig öt egyházmegye zsinati határozatainak szövegében azonosíthatók, ezek: 1292-1293 Mende, 1298 Novara, 1338 Pavia, 1320 Krakkó, 1382 Esztergom. A szöveg nyugatról kelet felé haladt. Ez önmagában nem zárja ki azt a lehetőséget, hogy az esztergomi zsinati határozatok első változatának megalkotása során a magyar föpapok szeme elött egy olyan szövegváltozat hevert, amely a krakkóihoz volt közelebb, nem pedig az ,itáliai szövegcsaládhoz” (Novara, Pavia), azaz a filológus kérdése a szövegrész közvetlen eredetéről továbbra is releváns lehet, ám kétségtelen tény, hogy ha a krakkói forrása is az esztergominak, semmiképpen nem az első megfogalmazása a szövegnek.

A szövegek közötti kapcsolat feltárásához ezek kollacionálása elengedhetetlen, mert enélkül nem lehet megtudni, hogy az adott esztergomi szövegrész bármely ponton tartalmaz-e szövegbetoldásokat, variánsokat, tájékoztat-e magyar jellegzetességekről, legyenek azok bármily’ apró megjegyzések.

Jelen helyen nincs mód a szövegek teljes összehasonlítására, és a közöttük lévő különbségek feltárására, ezért a szövegegyezések mértékét csak egy nagyon rövid példával szemléltetem.

${ }^{21}$ Instructions et constitutions de Guillaume Durand le Spéculateur publiées d'aprés le manuscrit de Cessenon, ed. Jos Berthelé, M. Valmary, Montpellier, 1900, a vonatkozó részek 9-94. 
Mende 1292-129322:

„Baptismus est primum ecclesiasticum sacramentum, qui est janua et fundamentum omnium sacramentorum, quo non recepto nullum aliud sacramentum valet recipi ad salutem; per illum enim est ingressus ad Christum et ad alia sacramenta. At ubi Christus non est fundamentum, nullum boni operis superest edificium. Et ubi sana fides non est, justicia esse non potest, quoniam justus ex fide vivit. Pro baptizandis itaque infantibus vel pro crismate premium aut precium recipere nolite. Ne propter vestri negligentiam infans aliquis sine baptismo decedat cavete. Unaqueque basilica fontes lapideos, si potest, habeat, alioquin ad hoc vas habeatur ligneum speciale."

Novara $1298^{23}$ :

„Baptismus est primum sacramentum, qui est ianua et fundamentum omnium sacramentorum, quo non recepto nullum aliud sacramentum valet recipi ad salutem. Per illum enim est ingressus ad Christum et ad alia sacramenta. At ubi Christus non est fundamentum, nullum boni operis superest edificium, et ubi sana fides non est, iustitia esse non potest, quoniam iustus ex fide vivit, pro baptizandis itaque infantibus vel pro crismate premium aut precium requirere nolite. Ne propter vestri negligentiam infans aliquis sine baptismo decedat, cavete. Unaqueque basilica baptismalis fontes lapideos, si potest, habeat. Alioquin vas ad hoc habeatur ligneum speciale."

Pavia $1338^{24}$ :

„Baptismus est primum sacramentum, janua et fundamentum omnium sacramentorum, quo non recepto, nullum aliud sacramentum proficit ad salutem, per illum enim est ingressus ad Christum et ad alia sacramenta et ubi Christus non est ibi nullum boni operis superest aedificium et ubi sana fides non est justitia esse non potest, quoniam justus ex fide vivit. Pro baptizandis infantibus praemium aut pretium accipere nolite vel etiam pro chrismate et ne propter vestri negligentiam, infans aliquis sine baptismo decedat, omnino cavete: unaquaeque basilica baptismalis fontes habeat lapideos, si potest habere, alioquin vas ligneum, ad hoc speciale."

Krakkó $1320^{25}$ :

„Baptismus est primum sacramentum, quo non recepto, nullum aliud sacramentum proficit ad salutem. Per illud enim est ingressus ad Christum et ad alia sacramenta, et ubi Christus non est fundamentum, nullum boni operis superest edificium etc. Pro baptizandis itaque infantibus vel pro crismate premium nolite

\footnotetext{
22 Berthelé ed. 1900, i. m. 13. A táblázatban M.

${ }^{23}$ BriacCA ed. 1971, i. m. 175. A táblázatban N.

${ }^{24}$ Bosisius ed. 1852, i. m. 178-179. A táblázatban P.

${ }^{25}$ HeyzMann ed. 1875, i. m. 4. A táblázatban K.
} 
requirere, ne propter vestri desidiam aut negligenciam infans aliquis decedat sine baptismo."

\section{Esztergom $1382^{26}$ :}

„Baptismus est primum sacramentum janua, et fundamentum omnium aliorum, quo non recepto, nulla alia prosunt ad salutem; per illud enim ingreditur ad Christum, ac ubi Christus non est, fundamentum nullius boni operis super est aedificandum. Primo, pro infantibus itaque baptizandis, vel pro confessionis sacramento praemium, aut pretium requirere nolite. Ne propter vestri negligentiam infans aliquis sine baptismo decedat, cavete. Una queque ecclesia baptismales fontes lapideos habeat, si potest habere, alioquin ad hoc aptum ligneum vas habeat speciale."

A szövegegyezést mutató fejezetek címei az egyes zsinati határozatokban:

\begin{tabular}{|c|c|c|c|c|}
\hline$M^{27}(1292-1293)$ & $N^{28}(1298)$ & $P^{29}(1338)$ & $K^{30}(1320)$ & $E 1^{31}(1382)$ \\
\hline $\begin{array}{l}\text { Fratres carissimi }+ \\
\text { De conversatione } \\
\text { clericorum } \\
\text { De scientia } \\
\text { sacerdotum }\end{array}$ & $\begin{array}{l}\text { Fratres carissimi }+ \\
\text { De vita et } \\
\text { conversatione } \\
\text { clericorum } \\
\text { De scientia quam } \\
\text { debent habere } \\
\text { clerici }\end{array}$ & $\begin{array}{l}\text { (De scientia } \\
\text { sacerdotum) } \\
\text { Fratres carissimi + }\end{array}$ & - & Fratres carissimi + \\
\hline De baptismo + & $\begin{array}{l}\text { (De administratione } \\
\text { sacramentorum) } \\
\text { De baptismo + }\end{array}$ & De baptismo + & $\begin{array}{l}\text { De sacramento } \\
\text { baptismi }+\end{array}$ & $\begin{array}{l}\text { Sequitur nunc de } \\
\text { primo sacramento, } \\
\text { videlicet baptismo + }\end{array}$ \\
\hline De confirmatione + & De confirmatione + & De confirmatione + & $\begin{array}{l}\text { De sacramento } \\
\text { confirmacionis }+\end{array}$ & $\begin{array}{l}\text { Sequitur secundum } \\
\text { sacramentum seu } \\
\text { confirmatio + } \\
\end{array}$ \\
\hline $\begin{array}{l}\text { De penitentia }+ \\
\text { De restitutionibus }\end{array}$ & De penitentia + & De poenitentia + & $\begin{array}{l}\text { De sacramento } \\
\text { penitencie }+\end{array}$ & $\begin{array}{l}\text { Sequitur tertium } \\
\text { sacramentum seu } \\
\text { poenitentia }+\end{array}$ \\
\hline $\begin{array}{l}\text { De sacramento } \\
\text { eucaristie }+\end{array}$ & De eucharistia + & $\begin{array}{l}\text { De sacramento } \\
\text { eucharistiae + }\end{array}$ & $\begin{array}{l}\text { De sacramento } \\
\text { eucaristie }+\end{array}$ & $\begin{array}{l}\text { Nunc instat quartum } \\
\text { sacramentum scilicet } \\
\text { eucharistia }+\end{array}$ \\
\hline
\end{tabular}

\footnotetext{
26 Batthyany, Leges III. 261. A táblázatban E1.

27 Berthelé ed. 1900, 9-94.

28 BRIACCA ed. 1971, i. m. 169-213.

29 Bosisius ed. 1852, i. m. 177-188.

${ }^{30}$ HeyzMann ed. 1875, i. m. 4-11.

31 Batthyany, Leges III, 260-274.
} 


\begin{tabular}{|c|c|c|c|c|}
\hline$M^{27}(1292-1293)$ & $N^{28}(1298)$ & $P^{29}(1338)$ & $K^{30}(1320)$ & $E 1^{31}(1382)$ \\
\hline $\begin{array}{l}\text { De extrema unctione } \\
+\end{array}$ & $\begin{array}{l}\text { De extrema } \\
\text { unctione }+\end{array}$ & $\begin{array}{l}\text { De extrema } \\
\text { unctione }+\end{array}$ & $\begin{array}{l}\text { De extrema } \\
\text { unccione }+\end{array}$ & $\begin{array}{l}\text { Nunc sequitur } \\
\text { quintum } \\
\text { sacramentum seu } \\
\text { extrema unctio + }\end{array}$ \\
\hline De ordine + & De ordine + & De ordine + & $\begin{array}{l}\text { De sacramento } \\
\text { ordinis }+\end{array}$ & $\begin{array}{l}\text { Nunc instat sextum } \\
\text { sacramentum } \\
\text { videlicet ordinis }+\end{array}$ \\
\hline De matrimonio + & De matrimonio + & De matrimonio + & $\begin{array}{l}\text { De sacramento } \\
\text { matrimonii }+\end{array}$ & $\begin{array}{l}\text { Nunc restat dicere de } \\
\text { septimo sacramento, } \\
\text { seu matrimonio }+\end{array}$ \\
\hline $\begin{array}{l}\text { De custodia et } \\
\text { contractatione } \\
\text { sacrarum rerum }+\end{array}$ & $\begin{array}{l}\text { De custodia et } \\
\text { contractatione } \\
\text { sacramentorum }+\end{array}$ & $\begin{array}{l}\text { De sacramentorum } \\
\text { custodia }+\end{array}$ & $\begin{array}{l}\text { De custodia } \\
\text { vestium }+\end{array}$ & $\begin{array}{l}\text { Sequuntur diversae } \\
\text { informationes, et } \\
\text { ponitur hic }+\end{array}$ \\
\hline $\begin{array}{l}\text { De divinorum } \\
\text { officiorum } \\
\text { celebratione + }\end{array}$ & $\begin{array}{l}\text { De divinorum } \\
\text { officiorum } \\
\text { celebratione + }\end{array}$ & $\begin{array}{l}\text { De divinorum } \\
\text { officiorum } \\
\text { celebratione }+\end{array}$ & $\begin{array}{l}\text { De divinorum } \\
\text { officiorum } \\
\text { celebracione }+\end{array}$ & $\begin{array}{l}\text { Tertia species } \\
\text { scientiae ponitur } \\
\text { haec }+\end{array}$ \\
\hline De officio misse & De officio misse & - & - & - \\
\hline $\begin{array}{l}\text { De animarum } \\
\text { atque ecclesiarum } \\
\text { regimine et } \\
\text { dispositione }+\end{array}$ & $\begin{array}{l}\text { De animarum } \\
\text { atque ecclesiarum } \\
\text { dispositione }+\end{array}$ & $\begin{array}{l}\text { De animarum } \\
\text { atque ecclesiarum } \\
\text { regimine }+\end{array}$ & $\begin{array}{l}\text { De animarum } \\
\text { et ecclesiarum } \\
\text { regimine }+\end{array}$ & $\begin{array}{l}\text { Nunc sequitur de } \\
\text { simonia vitanda } \\
\text { capitulum }+\end{array}$ \\
\hline De sepulturis + & De sepulturis + & De sepulturis + & - & $\begin{array}{l}\text { De sepulturis, et } \\
\text { qui in ecclesia, vel } \\
\text { coemiterio sunt } \\
\text { sepeliendi, et qui non, } \\
\text { et quibus debeant } \\
\text { denegari sacramenta } \\
+\end{array}$ \\
\hline De decimis + & $\begin{array}{l}\text { De decimis et } \\
\text { primitiis }+\end{array}$ & De decimis + & - & $\begin{array}{l}\text { Capitulum de } \\
\text { decimis, et qualiter } \\
\text { non solventes } \\
\text { debeant puniri, et } \\
\text { qui interdictum non } \\
\text { servaverunt }+ \\
\end{array}$ \\
\hline $\begin{array}{l}\text { De ecclesiastica } \\
\text { censura }+ \\
\text { (De iudeis) }\end{array}$ & $\begin{array}{l}\text { De censura } \\
\text { ecclesiastica }+\end{array}$ & $\begin{array}{l}\text { De censuris } \\
\text { ecclesiasticis }+\end{array}$ & - & $\begin{array}{l}\text { De sententia } \\
\text { excommunicationis } \\
\text { majoris, et minoris, } \\
\text { et aliis censuris et } \\
\text { effectu utriusque et } \\
\text { interdicti }+\end{array}$ \\
\hline var. & var. & var. & var. & var. \\
\hline
\end{tabular}


Míg a (jelen pillanatban) a hagyomány kiindulópontjának tekinthető mende-i egyházmegyei zsinati határozatok, valamint a novarai egyházmegyei zsinati határozatok két egymástól jól elkülönülö tartalmi részre oszlanak (institutiones et constitutiones), addig ez a két részre osztottság a hagyomány későbbi elemeinél, a paviai, a krakkói és az esztergomi zsinati határozatok esetén a szövegezés szintjén (szövegtagolás, fejezetcímek) már nem jelenik meg, azaz a mintákból átvett részek után semmi nem jelöli, hogy a zsinati határozatoknak, vagy a zsinati könyvnek egy másik része kezdődik el. Az egyházmegyei határozatok (és/vagy szinodális könyvek) a szövegük ezen pontján variálódni kezdenek. A tematikailag (és nagyrészt szövegezésében is maximum csak rövidült) egyező institutiones részeket egyedibb, minden bizonnyal a regionális hagyományokra érzékenyebb és a keletkezés ideje által is jóval inkább befolyásolt részek, constitutiones, követik.

\section{Redakciók}

Ebből pedig az következik, hogy esztergomi egyháztartományi lokális, partikuláris hagyománynak is a más zsinati könyvekből átvett első része lehet a kevésbé variábilis eleme, a második rész pedig a változóbb, több redakcióban rögzült elem, amelyet a határozatok kiadásának időpontja is befolyásolt. Így képzelhető el az, hogy az esztergomi egyházmegye zsinati határozatainak három eddig elkülönített, különböző redakciója (az egyszerüség kedvéért 1382=E1, 1450=E2, $1493=E 3$ ) is ezek után a szövegrészek után kezd el variálódni. A zsinati könyvnek ez az első nagy négyosztatú tematikai egysége gyakorlatilag változatlan tartalmú marad, és ez a rész nemcsak az esztergomi egyházmegye összes, hanem a veszprémi egyházmegye $1515-$-o $^{32}$ és a kalocsai egyháztartományhoz tartozó váradi egyházmegye 1524-es zsinati határozatainak elején is szinte változatlan formában maradt ránk. ${ }^{33}$

A filológus szemével a magyar hagyomány zsinati határozatainak első részei a források azonosítása miatt rendkívül érdekesek lettek, hiszen szinte egyedülálló módon olyan latin szövegekröl van szó, amelyeket számos más anyanyelvü középkori terület latin megszövegezésében, és a magyar anyanyelvü terület latin megszövegezésében is ismerünk, így a latin nyelvhasználati különbségekröl sokat elmondhat a szövegek kollacionálása. Amit azonban a filológusok megnyertek a vámon, a történészek elveszítették a réven. A határozatok első részei olyan szövegek, amelyeket a 13. század végi klasszikus kánonjog kiváló művelője, Durandus alkotott meg, és valamilyen közvetítéssel, valamikor Esztergomba kerültek, sokkal inkább a klasszikus középkori kánonjog szövegei, mint az esztergomi egyházmegye saját hagyományának és szokásainak emlékei. Ez a tény felértékeli a zsinati határozatok variábilisabb második részének értékét, hiszen ezek esetén

32 Solymosi 1997, i. m. 45-80.

${ }^{33}$ A váradi egyház 1524. évi zsinati határozatai, ed. Jaczkó Sándor, Bp., Balassi, 195-212. 
még nem ismerjük a forrásokat, így továbbra is feltételezhetjük, hogy számos határozat szövege valóban a középkori esztergomi egyházmegyében született, szövegeződött meg, és valóban úgy kell elképzelni, hogy ezek a részek egy-egy esztergomi érsek tényleges zsinati tevékenységét (vagy annak egy időpillanatát) közvetítik számunkra.

A kutatás eddigi ismeretei szerint az esztergomi egyházmegye zsinati könyvét eredeti formájában 1382-ben hirdette ki Demeter esztergomi érsek (a továbbiakban E1), az első átdolgozott változat pedig Szécsi Dénes esztergomi érseksége idejéből, 1450-ből való (a továbbiakban E2). ${ }^{34}$ A brassói kódexben található redakciója az esztergomi egyházmegye zsinati határozatainak Kanizsai János esztergomi érsek szinodális könyve ${ }^{35}$ (a továbbiakban a jobb elkülöníthetőség kedvéért Br), és a szöveg az 1382-es szövegváltozathoz, azaz az E1-hez áll közel, annak módosított, ünneplistával ellátott változata. ${ }^{36}$

A következő táblázatban a három redakció (E1, E2, Br) azon rubrikáinak címei szerepelnek, amely pontnál elkezdenek variálódni a szövegek, ahol már nem a fent ismertetett Durandustól eredő szövegek a határozatok forrásai:

\begin{tabular}{|c|c|c|}
\hline E1 (1382) & $E 2(1450)$ & Br (1394/ XVmed $)$ \\
\hline $\begin{array}{l}\text { De vestimentis clericorum } \\
\text { deferendis, et quibus pannis et } \\
\text { quo habitu clerici, et religiosi uti } \\
\text { debeant, et qua poena puniantur }\end{array}$ & $\begin{array}{l}\text { De habitu clericorum } \\
(=\mathrm{E} 1)\end{array}$ & $\begin{array}{l}\text { De vita et honestate } \\
\text { clericorum } \\
(=\mathrm{E} 1=\mathrm{E} 2)\end{array}$ \\
\hline $\begin{array}{l}\text { De clericis concubinariis, qua } \\
\text { poena sunt puniendi, et quales } \\
\text { debent habere mulieres in domibus } \\
\text { eorum }\end{array}$ & $\begin{array}{l}\begin{array}{l}\text { De clericis concubinariis } \\
(=\mathrm{E} 1)\end{array} \\
\text { Additio de concubinariis }\end{array}$ & $\begin{array}{l}\text { De continencia clericali } \\
\text { sequitur } \\
(=\mathrm{E} 1=\mathrm{E} 2)\end{array}$ \\
\hline $\begin{array}{l}\text { Quod clerici in domibus eorum } \\
\text { tabernent, nec mercimoniis } \\
\text { laicalibus se imisceant }\end{array}$ & $\begin{array}{l}\text { Quod clerici in domibus } \\
\text { eorum vinum non tabernent } \\
(=\mathrm{E} 1)\end{array}$ & $\begin{array}{l}\text { Ne persone ecclesiastice } \\
\text { secularia negocia exerceant } \\
(=\mathrm{E} 1=\mathrm{E} 2)\end{array}$ \\
\hline $\begin{array}{l}\text { Qualiter, et qua hora missa, et alia } \\
\text { divina officia debeant celebrari, et } \\
\text { quibus indumentis uti debeant }\end{array}$ & $\begin{array}{l}\text { De hora missarum } \\
(=\mathrm{E} 1)\end{array}$ & $\begin{array}{l}\text { Nota alia clericis necessaria } \\
(=\mathrm{E} 1 \mathrm{Qualiter} . .=\mathrm{E} 2)\end{array}$ \\
\hline $\begin{array}{l}\text { De promovendis ad sacros ordines, } \\
\text { et qua poena puniantur praesentati, } \\
\text { et praesentantes contra formam } \\
\text { hujus constitutionis facientes }\end{array}$ & $\begin{array}{l}\text { Quales sunt promovendi ad } \\
\text { ordines } \\
(=\mathrm{E} 1)\end{array}$ & $(=\mathrm{E} 1 \mathrm{De}$ promovendis $=\mathrm{E} 2)$ \\
\hline $\begin{array}{l}\text { De usurpantibus bona ecclesiae } \\
\text { jura, et jurisdictionis bona, de } \\
\text { poenis eorundem et tributariorum }\end{array}$ & $\begin{array}{l}\text { De usurpantibus iura } \\
(=\mathrm{E} 1)\end{array}$ & $\begin{array}{l}\text { Nota alia statuta } \\
(=\text { E1 De usurpantibus =E2) }\end{array}$ \\
\hline
\end{tabular}

\footnotetext{
34 ERDö 2001, i. m. 41.

35 Solymosi 1997, i. m. 31.

36 Solymosi 1998, i. m. 91.
} 


\begin{tabular}{|c|c|c|}
\hline E1 (1382) & $E 2(1450)$ & $\mathrm{Br}(1394 / \mathrm{XVmed})$ \\
\hline $\begin{array}{l}\text { De poena non confirmatorum in } \\
\text { beneficiis capitulum }\end{array}$ & $\begin{array}{l}\text { De pena non confirmatorum } \\
\text { (=E1) }\end{array}$ & $(=\mathrm{E} 1 \mathrm{De}$ poena $=\mathrm{E} 2)$ \\
\hline $\begin{array}{l}\text { De poenis non residentium in } \\
\text { beneficiis capitulum }\end{array}$ & $\begin{array}{l}\text { De penis non residentium in } \\
\text { beneficiis } \\
\text { Contra absentes } \\
(=\mathrm{E} 1)\end{array}$ & $(=\mathrm{E} 1 \mathrm{De}$ poenis non...=E2) \\
\hline $\begin{array}{l}\text { Qualiter testamenta fieri debent in } \\
\text { praesentia sacerdotis parochialis }\end{array}$ & $\begin{array}{l}\text { Qualiter testamenta fiant } \\
\text { (=E1) }\end{array}$ & $\begin{array}{l}(=E 1 \text { Qualiter testamenta }= \\
\text { E2) }\end{array}$ \\
\hline $\begin{array}{l}\text { Quod relicta ad pias causas et male } \\
\text { ablata intra sex menses executioni } \\
\text { demandentur, executiones non } \\
\text { facientes sunt excommunicati }\end{array}$ & $\begin{array}{l}\text { De testamentis } \\
(=\mathrm{E} 1)\end{array}$ & $(=\mathrm{E} 1$ Quod relicta=E2) \\
\hline \multirow[t]{10}{*}{$\begin{array}{l}\text { Sequitur a quibus et quomodo } \\
\text { debent vitari interdicti et } \\
\text { excommunicati }\end{array}$} & $\begin{array}{l}\text { De excommunicatis } \\
\text { visitandis } \\
(=\mathrm{E} 1)\end{array}$ & (=E1 Sequitur a quibus=E2) \\
\hline & $\begin{array}{l}\text { Sequuntur constitutiones } \\
\text { aliae }\end{array}$ & $\begin{array}{l}\text { Secuntur ammonitiones } \\
\text { (=E2 Sequuntur részben) }\end{array}$ \\
\hline & & $\begin{array}{l}\text { Secuntur alie ammonitiones } \\
\text { (Jelentős máshonnan eddig } \\
\text { ismeretlen szövegtöbblet!) }\end{array}$ \\
\hline & & $\begin{array}{l}\text { Sequuntur nove } \\
\text { constitutiones de sede } \\
\text { Strigoniensi } \\
\text { (=E2 Sequuntur } \\
\text { constitutiones aliae eleje) }\end{array}$ \\
\hline & De religiosis & $\begin{array}{l}\text { De religiosis et questionariis } \\
\text { sequitur } \\
(=\mathrm{E} 2)\end{array}$ \\
\hline & De officio archidiaconorum & $\begin{array}{l}\text { Sequitur de officio } \\
\text { archidiaconorum } \\
(=\mathrm{E} 2)\end{array}$ \\
\hline & De commessationibus & $\begin{array}{l}\text { De commessacionibus } \\
(=\mathrm{E} 2)\end{array}$ \\
\hline & De usurariis & $\begin{array}{l}\text { De usurariis } \\
(=\mathrm{E} 2)\end{array}$ \\
\hline & De usurpatoribus & $\begin{array}{l}\text { De usurpatoribus } \\
\text { ecclesiarum } \\
(=\mathrm{E} 2)\end{array}$ \\
\hline & $\begin{array}{l}\text { Contra abbates sancti } \\
\text { Benedicti }\end{array}$ & $\begin{array}{l}\text { Item alie constituciones } \\
\text { (A szövegtöbbletben } \\
\text { hozott szöveg egy részének } \\
\text { megismétlése.) }\end{array}$ \\
\hline
\end{tabular}




\begin{tabular}{|l|l|l|}
\hline E1 (1382) & \multicolumn{1}{|c|}{ E2 (1450) } & \multicolumn{1}{|c|}{ Br (1394/XVmed) } \\
\hline & De festivitatibus colendis & $\begin{array}{l}\text { Item alie constituciones } \\
\text { (A szövegtöbbletben } \\
\text { hozott szöveg egy részének } \\
\text { megismétlése) }\end{array}$ \\
\hline & $\begin{array}{l}\text { (Sine titulo) } \\
\text { (Ünneplista) }\end{array}$ \\
\hline & $\begin{array}{l}\text { Casus episcopales } \\
\text { Et isti infrascripti remittantur } \\
\text { ad dominum archiepiscopum } \\
\text { vel eius in spiritualibus } \\
\text { vicarium pro solempni } \\
\text { poenitentia }\end{array}$ \\
& $\begin{array}{l}\text { Nota casus papales } \\
\text { (Rezervált esetek } \\
\text { listája, eddig ismeretlen } \\
\text { szövegtöbblet!) }\end{array}$ \\
\hline
\end{tabular}

Mint az a táblázatból látszik, az esztergomi szinodális könyv $\mathrm{Br}$ változata mind az E1, mind az E2 redakció zsinat határozatait hozza, azaz valójában az E2 változathoz áll közelebb. A brassói kódexben található szöveg liber synodalis, zsinati könyv talán abban az értelemben is, amelyet a magyar szakirodalomban Erdö Pétertől ismerünk: „liber synodalis..., mint azoknak a zsinati szövegeknek az öszszessége, amelyeket egyazon kéziratos kódexbe írtak egymás után”. [...] Olyan zsinati határozatokat tartalmazó kötet, melybe a plébánosok utólag beírták a későbbi zsinati határozatok által eszközölt változtatásokat." 37

Ezt a szöveg szerkezetének több jellegzetességével lehet bizonytani. Egy ponton az alábbi határozat következik:

„Secuntur alie ammoniciones.

Item consequuntur breves informaciones seu ammoniciones. In presenti constitucione statuimus, ut nullus presbiter, nullus ecclesieque rector ab aliquo baptizando nec pro penitencia, neque pro ewcaristia, neque pro crimate, neque pro extrema unccione, neque pro aliquo sacramento denarium exigant, sed sponte oblatos recipiat.

Item cum propter dilacionem temporis plerumque infantes sine baptismate moriuntur, statuimus, ut archidiaconi, vicearchidiaconi, rectores ecclesiarum et eorum capellani singulis dominicis diebus et festivis moneant parochianos suos,

37 ERDÖ 2001, i. m. 25. 
ut infantes quanto citius possunt ad baptizandum deferant et saltem ultra octo dies eos baptizare non differant.

Item statuimus, ut similiter suos parochianos moneant et inducant, ne infantes in lecto secum teneant propter periculum opressionis, sicut multociens contingit. Sed si necessitas urgeat eos secum in lecto cum omni diligencia et Dei timore habeant et bene custodiant." ${ }^{38}$

Több oldallal később pedig ismét más címfelirattal, az alábbi:

„Item alie constituciones

Praeterea cum propter dilacionem temporis plerumque infantes sine baptismate moriuntur, presenti constitucione statuimus, ut archidiaconi, vicearchidiaconi, plebani et alii ecclesiarum rectores singulis diebus dominicis et festivis moneant parochianos suos, ut infantes quanto cicius possunt ad baptizandum deferant et saltem ultra octo dies baptizando non differant. Si quis autem contrarie presumpserint eis firmissimum teneatis interdictum, tam diu quam diu ipsum baptizare facere curaverint. In iurisdiccione nostra pravus inolevit abusus, quod parentes, quos gignunt propria persona ex desidia ipsorum opprimunt. Et cum scriptum sit 'nemo carnem suam odio habuerit', presenti constitucione statuimus, quod singulis diebus dominicis archidiaconi, vicearchidiaconi, presbiteri et alii ecclesiarum rectores publice parochianos moneant et inducant, ut infantes in lecto secum non teneant, et si omnino necessitas ingruerit secum in lecto eius habere cum omni diligencia et Dei timore secum habeant et bene custodiant." ${ }^{\prime 39}$

Mint látható, a két határozat ugyanaz, csak úgy kerülhetett kétszer egymás után a szövegbe, ha a brassói kódexben található liber synodalis úgy jött létre, hogy több, különböző időpontban kihirdetett, kiadott zsinati határozatot, zsinati könyvet egymás után másoltak bele. Mivel a különböző időpontokban kihirdetett zsinati könyvek bizonyára szinte soha nem változtatták meg teljesen a korábbi zsinati könyvek szövegét, hanem csak apró módosításokat eszközöltek, vagy határozatok hozzátoldásokkal éltek, ezért ugyanazoknak a határozatoknak a szövegét többször egymás után nem volt értelme bemásolni, mert azok egymással megegyeztek. A brassói kódexben található liber synodalisnak erre a szerkesztési módjára egy helyen utal is a szövege:

„Cetera, que vacans (?) incipiendo sic:

$» N$ e autem propter irreverenciam ira Dei veniat, statuimus, quod quilibet sacerdos etc.《

${ }^{38}$ DF 286635 (105. fénykép). Ezt a határozatot eddig csak az 1515-ös veszprémi zsinati határozatokból ismertük: Solymosi 1997, i. m. 90.

${ }^{39}$ DF 286635 (123. fénykép). 
Que in quinto filio (sic, recte forsan folio) precedencium institucionum iuxta crucem per ordinem usque ad finem." 40

A szöveg ezen a ponton visszautal egy öt fólióval korábbi határozatra, ahol a $\mathrm{Ne}$ autem propter irreverenciam ira Dei veniat kezdetü határozat végig be van jegyezve, a határozat szövege mellett pedig valóban egy apró vörös kereszt, a kereszt jele jelzi (,,iuxta crucem”) ${ }^{41}$, hogy hol kezdődnek azok a határozatok, amelyeket a másoló másodjára már kihagyott és nem írta le teljes szöveggel, mert egyszer már bejegyezte őket.

A fejezetben elmondottakat a következő módon foglalhatjuk össze. Míg az esztergomi szinodális könyv E1 és E2 változatának szövegéhez hozzárendelhetünk egy-egy kiadási időpontot és egy-egy esztergomi érseket (1382 Demeter, 1450 Szécsi Dénes), addig ez zsinati könyv Br változatára nem feltétlenül igaz. Az itteni liber synodalis egy olyan bevezetővel kezdődik, amely a határozatok kiadását Kanizsai János esztergomi érsekhez köti, ám már a korábbi kutatás is felfigyelt rá, hogy a szöveg talán egy érsek (Kanizsai János) müködése teljes idején kiadott zsinati határozatokat tartalmazza, azaz egy érsek zsinati tevékenységének több fázisát. ${ }^{42} \mathrm{~A}$ határozatok előzetes megvizsgálása után az sem látszik teljesen lehetetlennek, hogy a Br szövegváltozat egy olyan zsinati könyv, amely nem csupán egy (Kanizsai János), hanem több (Kanizsai János, Szécsi Dénes) esztergomi érsek zsinati tevékenységének emlékeit együttesen őrzi.

\section{Szövegtöbbletek}

Ahogyan a filológusok mondanák, a brassói kódex (és ezáltal a Br szövegváltozat) az esztergomi zsinati határozatok első része, a szentségekről szóló rész tekintetében egy codex descriptus. A szöveget az esztergomi zsinati hagyomány más forrásaiból is ismerjük, helyenként sokkal érthetőbb és kevésbé romlott változatban. Ami azonban a kódexben található szöveg redakcióját illeti, az annyira egyedi, hogy utóbb segíthet a szöveg egyes rétegeit egymástól elkülöníteni, bizonyos határozatokat az esztergomi érsekek zsinati tevékenységének bizonyos fázisaihoz kötni. Ami azonban még ennél is értékesebbé teszi a Br szövegváltozatot, azok a szövegbetoldások, amelyeket eddig egyetlen más egyéb forrásból sem ismertünk, nem tudtuk, hogy ezek a határozatok is az esztergomi zsinati hagyomány részét képezték. Ezek a szövegbetoldások a fenti táblázatban jelölt helyeken találhatók. Együttesen mintegy 15000 leütésnyi máshonnan ismeretlen szöveget tesznek ki. Reményeim szerint a teljes zsinati könyv átírását disszertációm melléklete fogja tartalmazni, így ezen a helyen az értelmezés és a források feltárása nélkül csak

\footnotetext{
${ }^{40}$ DF 286635 (125. fénykép).

${ }^{41}$ DF 286635 (105. kép), a kereszt jele az alsó sorok mellett a bal margón látható.

42 Solymosi 1998, i. m. 93.
} 
három pár soros különböző helyről vett példával szemléltetem és bizonyítom a fenti állítást:

„Item cum nichil in sacramentis est maius et sanccius corpore Christi et propter negligenciam sacerdotum minus caute ecclesie sacramenta custodiencium alioquin malifice et incantatrices ipsum corpus dominicum, oleum sanctum et alia occulta sacramenta dampnabiliter pertractant, statuimus eciam, ut quilibet sacerdos ipsum corpus domini in pixide munda, seu ladula cum panno mundissimo sub conclavi et fideli custodia diligentissime conservet, ne mus aut aranea ipsum contingat, vel sinistra manus pertractet. Similiter et alia omnia sacramenta fideli custodia caveant, ne propter incuriam sacerdotum divina indignacio in clerum et populum graviter exardescat. [... $]^{\prime 43}$

„Item monemus omnes religiosos quorumcumque ordinum, ut ad iura parochialia exercenda se nullomodo intromittant, sicut facere consueverunt in maioribus festivitatibus, videlicet in Pascha carnes benedicendo, et in festo purificacionis Beate Virginis candelas, in Ramis Palmarum ramos similiter benedicendo parochianis ecclesiarum ad eos confluentibus, et similiter, que ad ipsos pertinere minime dinoscuntur $[\ldots] .{ }^{44}$

„Casus episcopales

Item coitus cum moniali consecrata vel non consecrata

Item mulier coiens cum religioso

Item percussor patris vel matris

Item deflorans virginem vi opressam vel seductam

Item machinans in mortem coniugis $[\ldots]^{45}$

Mivel a késő középkori esztergomi szinodális könyv brassói kódexben található változatának előzetes áttekintése a határozatok eddig ismeretlen forrásait hozta felszínre, valamint eddig ismeretlen szövegtöbblettel napvilágra kerülésével is szolgált, ezért a közeli jövőben a zsinati könyv teljes szövegének átírása, kiadása és a redakció részletes elemzése elkerülhetetlen feladatnak látszik ${ }^{46}$.

${ }^{43}$ DF 286635 (105. fénykép).

${ }^{44}$ DF 286635 (113. fénykép).

${ }^{45}$ DF 286635 (127. fénykép).

46 Szeretnék köszönetet mondani doktori témavezetőimnek, Solymosi Lászlónak és Szovák Kornélnak értékes tanácsaikért, javaslataikért és segítségükért. Köszönöm továbbá Rowan Dorin (Stanford University, Assistant Professor of History) segítségét, aki hozzáférést adott számomra a Stanford Egyetemen készülő Corpus Synodalium középkori európai zsinati adatbázishoz és szövegkorpuszhoz. A késő középkori esztergomi zsinati könyv forrásai és allúziói feltárásához 2019. június 4-e óta ezt az adatbázist is használom. Valamint köszönet illeti munkatársaimat az MTA-ELTEPPKE Ókortudományi Kutatócsoportjában, mert kötetlen beszélgetéseink alkalmával számos ötle- 
SOMOGYI, SZILVIA

\title{
Du livre synodal d'Esztergom: aux traces de nouvelles sources, de nouvelles rédactions et de suppléments
}

\author{
Études préliminaires pour une dissertation
}

Le vestige principal de l'activité concilaire en Hongrie à la fin des temps médiévaux est le texte latin que la recherche connaît sous le nom du livre synodal d'Esztergom. Jusqu'à aujourd'hui, trois rédactions importantes sont connues $(1382,1450,1493)$ de cette source qui renferme les résolutions conciliaires du diocèse d'Esztergom. La source majeure d'une partie du texte est la publication par Nanker, évêque de Cracovie (1320), des résolutions conciliaires polonais. Notre étude est une récapitulation des enseignements produits par la transcription préliminaire d'une version jusqu'ici peu étudiée du texte. A l'occasion de l'analyse de la version que renferme le codex de Brassó (1390/ $\mathrm{XVmed),} \mathrm{je} \mathrm{suis} \mathrm{arrivée} \mathrm{á} \mathrm{la} \mathrm{conclusion} \mathrm{que} \mathrm{la} \mathrm{source} \mathrm{cracovienne} \mathrm{mentionnée} \mathrm{n'est} \mathrm{pas} \mathrm{la} \mathrm{premiè-}$ re formulation des résolutions conciliaires reprises par le texte d'Esztergom. La partie consacrée aux sacrements et à leur conservation se retrouve, par exemple, dans les résolutions publiées par 5 diocèses différents. La première formulation des résolutions remonte à la fin du $13^{\mathrm{e}}$ siècle, plus exactement à la rédaction préparée par Wilhelmus Durandus (juriste canonique de renom) pour le diocèse de Mende, en 1292-1293. La première partie du livre conciliaire de Durandus a pris une vie autonome: en forme abrégée, elle est devenue la source des résolutions conciliaires de diocèses variés. Les cinq documents identifiés sont les suivants: Mende 1292-1293 (Wilhelmus Durandus püspök), Novara 1298 (l'évêque Papiniano Della Rovere), Pavie 1338 (l'évêque Giovanni [IV.] Fulsoni), Cracovie 1320 (l'évêque Nanker), Esztergom 1382 (l'archévêque Demeter).

Le livre synodal que renferme le codex de Brassó fournit également d'autre nouveautés à la recherche. D'un côté, c'est une rédaction quasi inconnue des résolutions conciliaires d'Esztergom, de l'autre, on y trouve un important corpus textuel supplémentaire, de 10-15 mille caractères environ.

Keywords: medieval canon law, synod, medieval Synodal Book of Esztergom, medieval councils of Esztergom, sources of medieval canon law.

tet adtak és adnak. A tanulmány megírása óta a késő középkori esztergomi zsinati könyv különböző redakcióinak összehasonlítását már elvégeztem, ez számos ponton felülírja, továbbfejleszti jelen írás megállapításait a redakciók egymáshoz való viszonyáról. Ezeket az eredményeket reményeim szerint a közeljövőben szintén ismertethetem valahol. 